prof. dr hab. inż. Janusz Mielniczuk

Politechnika Poznańska

Instytut Pojazdów Szynowych ,TABOR”

dr inz. Marek Malinowski

Uniwersytet Zielonogórski

\title{
Modele materiałów porowatych w projektowaniu konstrukcyjnych elementów powierzchniowych
}

\author{
$W$ artykule przedstawiono podstawy modelowania materiatów konstrukcyjnych oraz omówiono \\ podstawowe właściwości strukturalne i mechaniczne materiałów porowatych. Dla założonego \\ modelu sprężystego materiatu porowatego określone zostały wytrzymatość $i$ stateczność \\ elementów powierzchniowych-prostokatnej płyty i powtoki walcowej. \\ Artykut powstat w wyniku realizacji tematu badawczego $\mathrm{nr}$ 5T07C02825 KBN pt. ,, Metody oraz \\ projektowanie cech konstrukcyjnych elementów powierzchniowych o strukturze porowatej”.
}

\section{Uwagi o modelowaniu materialów konstrukcyj- nych}

Historycznie ukształtowane metody i normy projektowania elementów konstrukcji w większości oparte są na badaniach zachowania się materiału w jednoosiowych stanach naprężenia. Wytężenie danej konstrukcji w niebezpiecznym punkcie sprawdza sie za pomocą klasycznych hipotez wytrzymałościowych, opartych na założeniach idealizacji procesu. Ponieważ rzeczywiste procesy mogą się różnić znacznie od wynikających $\mathrm{z}$ analizy teoretycznej, w projektowaniu konstrukcji przyjmuje się duże współczynniki bezpieczeństwa. Przyjęcie dużych współczynników bezpieczeństwa na ogół prowadzi do nieuzasadnionego przewymiarowania przekrojów elementów konstrukcji. Mimo to w niektórych przypadkach warunki bezpieczeństwa mogą nie być spełnione. Wynika stąd, że aby uściślić metody projektowania i zwiększyć niezawodność konstrukcji, należy opracować nowe modele matematyczne badanych procesów. Poprawne modele można uzyskać na podstawie obiektywnych modeli fizycznych, których własności i właściwości oparte są na weryfikacji właściwie zaprogramowanych i wykonanych badań doświadczalnych. Korzystne jest rozpatrzenie kompletu równań do rozwiązania zagadnień początkowo-brzegowych. Dobre rozwiązanie zagadnień początkowo-brzegowych konstrukcji zależy głównie od poprawnego doboru równań konstytutywnych. Równania powinny być budowane dla jednorodnych stanów naprężenia i weryfikowane doświadczalnie. Całość zagadnienia można ująć jako identyfikację procesu w materiale. Procedura poprawnego opisu zjawisk w materiale może być zapożyczona $z$ problematyki sterowania [2] i modelowania dynamicznych układów mechanicznych $[1,3,4,6]$. Procedurę tę możemy podzielić na cztery etapy:

1) możliwie dokładne wstępne określenie badanego materiału, jego istotnych cech oraz ustalenie jego modelu fizycznego,

2) znalezienie modelu matematycznego opisującego model fizyczny,

3) analiza równań opisujących model fizyczny,

4) synteza i optymalizacja badanego materiału, zmierzająca do ustalenia struktury równań, ich parametrów i spełniająca jego właściwości.

W mechanice ciał odkształcalnych, a więc i w wytrzymałości materiałów i np. w teorii obróbki plastycznej, podstawowym modelem materiału jest ośrodek ciagły, kontinuum materialne. Zgodnie $\mathrm{z}$ takim modelem przyjmuje się, że materia wypełnia konkretne formy geometryczne, ukształtowane w elementy maszyn czy konstrukcji, w sposób ciągły a wszelkie zjawiska towarzyszące przemieszczaniu jej cząstek pod wpływem obciążeń zewnętrznych mają też charakter ciagły. Kontynualny model materiału odegrał podstawową rolę $\mathrm{w}$ rozwoju techniki i również obecnie jest najlepszym opisem makroskopowego zachowania się ciał stałych. Przyjęcie takiego modelu i wprowadzanie do niego kolejnych uproszczeń czy założeń prowadzi do tworzenia modeli materiałów o specyficznych właściwościach takich jak na przykład materiały liniowo sprężyste czy sztywno-plastyczne. Określenie modelu zależne jest od potrzeb i dziedziny badań. Tworzenie modelu fizycznego (mechanicznego) a następnie na jego podstawie modelu matematycznego (procedura identyfikacji) zawsze powinno poprzedzać ustalenie:

- celu modelowania,

- $\quad$ praw fizycznych spełnianych przez materiał,

- właściwości jakościowych i ilościowych materiału.

Cel modelowania może być inny dla konstruktora a inny dla technologa.

W artykule ograniczono się do omówienia modeli materiałów porowatych w zakresie ich właściwości mechanicznych. Właściwości te, na przykład moduły sprężystości czy granice plastyczności, będą funkcjami parametrów struktury wewnętrznej - porowatości, gęstości, ukierunkowania i innych. Im bogatsza jest nasza wiedza o badanym materiale, tym doskonalszy model można zbudować.

Wykorzystanie sformułowanego modelu matematycznego w rozwiązywaniu zagadnień początkowo-brzegowych prowadzi do określenia w sposób teoretyczny zachowania się (wytrzymałość, odkształce- 
nie, stateczność) modelowanego materiału, elementu, konstrukcji [5,7]. Weryfikacja doświadczalna (także numeryczna) uzyskanych wyników jako końcowy etap modelowania pozwala ocenić słuszność poczynionych założeń i ewentualnie wskazać poprawki, czyniąc model bliższym rzeczywistości.

\section{Właściwości materiałów porowatych}

Ośrodki porowate stanowią znaczącą grupę materiałów, również konstrukcyjnych. Występują w postaci materiałów naturalnych (skały, grunty), materiałów biologicznych (tkanki kostne, drewno) czy też w postaci dużej różnorodności materiałów technicznych (spieki, betony, wkłady filtrów, pianki itp.). Mechanika takich odkształcalnych ośrodków porowatych, szczególnie nasyconych cieczą, znajduje coraz szersze praktyczne zastosowanie. Znaczenie tej tematyki wyznaczają liczne zagadnienia inżynierskie z zakresu mechaniki gruntów i skał, kopalnictwa i eksploatacji złóż ropy naftowej i gazu, teorii filtracji, metalurgii proszków itd. Makro-kontynualna teoria ośrodków porowatych nasyconych i nienasyconych cieczą znajduje również zastosowanie $\mathrm{w}$ projektowaniu i badaniach elementów konstrukcji takich jak na przykład porowate łożyska, porowate przegrody i wypełnienia, części biozastępcze (implanty), katalizatory i filtry.

W artykule omówiono zasadnicze cechy charakteryzujące strukturę porów. Spośród licznego zbioru różnorodnych wielkości, związanych z porowatym materiałem, przedstawiono parametry struktury ważne dla opisu zagadnień mechaniki takich materiałów, wykorzystując głównie interpretację geometryczna. Szczególną uwagę poświęcono roli parametrów struktury - głównie porowatości - przy określaniu zastępczych stałych (funkcji) materiałowych dla porowatych materiałów sprężystych oraz przy modelowaniu plastycznego zachowania się materiałów porowatych. Obserwacje i badania prowadzone nad ośrodkami porowatymi wskazują, że intensywność występowania porów w materiale, określona porowatością lub gęstością względną, ma zdecydowany wpływ na charakterystyki materiałowe a więc i na procesy zachodzące $\mathrm{w}$ takich materiałach jak na przykład odkształcenia czy transport masy i ciepła.

Porowatość jest jedną z podstawowych cech geometrycznych materiałów porowatych. Powszechnie rozumiana jest jako stosunek objętości porów do całkowitej objętości ośrodka. ,Mając na uwadze modelowanie metodami kontinuum materialnego, wielkość ta (podobnie jak i inne) powinna mieć charakter lokalnej wielkości polowej. Wymaga to określenia pewnej reprezentatywnej objętości ośrodka, na której definiowania takich wielkości można dokonywać, tzn. aby lokalne wielkości polowe (funkcje współrzędnych $\boldsymbol{x}$ punktu w obszarze ośrodka) miały charakter średnich z obszarów o charakterystycznym wymiarze dużo większym od wymiarów pojedynczych porów lub ziaren lecz dużo mniejszym od wymiaru charakterystycznego dla całego ciała, np. wymiaru elementu lub konstrukcji. Na podstawie powyższego rozumowania definicję porowatości objętościowej ośrodka w punkcie $\boldsymbol{x}, f_{V}(\boldsymbol{x})$, można wyrazić jako iloraz objętości wszystkich porów $V_{p}$ w obszarze reprezentatywnym do objętości tego obszaru $V$, tzn.

$$
f_{V}(x)=\frac{V_{P}}{V}
$$

Rozróżnienie porów otwartych (połączonych ze sobą) od zamkniętych prowadzi do określenia porowatości efektywnej i nieefektywnej, co jest istotne w opisie przepuszczalnych materiałów porowatych $\mathrm{z}$ filtrującym w nich płynem.

W opisie struktury ośrodków granulowanych, ziarnistych wprowadza się zamiast parametru porowatości tzw. wspótczynnik porowatości, p(x), zdefiniowany jako stosunek lokalnej objętości porów $V_{P}$ do objętości szkieletu (ziaren) $V_{\mathrm{S}}$. Zatem:

$$
p(\boldsymbol{x})=\frac{V_{P}}{V_{S}}=\frac{f_{V}}{1-f_{V}}
$$

Często używaną wielkością $\mathrm{w}$ charakteryzowaniu ośrodków porowatych jest gęstość względna, $r(\boldsymbol{x})$, rozumiana jako iloraz gęstości materiału porowatego $\rho$ i gęstości materiału szkieletu $\rho_{S}$. Można ją wyrazić przez porowatość objętościową następująco:

$$
r(\boldsymbol{x})=\frac{\rho}{\rho_{S}}=1-f_{V}
$$

Postępując podobnie jak przy określaniu porowatości objętościowej można zdefiniować porowatość powierzchniową $f_{A}$ oraz porowatość liniową $f_{L}$ ośrodka porowatego.

Wewnętrzna powierzchnia właściwa jest ważną cechą materiałów porowatych i jest powszechnie stosowana w opisie struktury skał, sorbentów, katalizatorów, wkładów filtrujących itp. Definiuje się ją jako iloraz całkowitej powierzchni wewnętrznej porów (ziaren) $S_{P}$ W reprezentatywnej objętości do tej objętości $V$, a więc

$$
\Sigma_{P}=\frac{S_{P}}{V}
$$

Dla materiałów granulowanych wewnętrzną powierzchnię właściwą wyraża się częściej w funkcji objętości szkieletu (ziaren) zawartego $\mathrm{w}$ materiale $\mathrm{i}$ wówczas

$$
\Sigma_{S}=\frac{S_{P}}{V_{S}}=\frac{S_{P}}{\left(1-f_{V}\right) V}=\frac{\Sigma_{P}}{1-f_{V}}
$$

Omówione powyżej wielkości porowatości są bardzo ważnymi parametrami struktury, lecz z jednej strony nie zależą w sposób jawny od wielkości porów zaś z drugiej nie uwzględniają kierunkowych właściwości struktury. Konieczne jest zatem wprowadzenie charakterystyk liniowych i tensorowych. 
Promień hydrauliczny, $r_{h}$, jest wielkością uwzględnianą $\mathrm{w}$ opisie przepływów przez materiał porowaty i dla objętości reprezentatywnej definiowany jest jako iloraz objętości porów do ich powierzchni wewnętrznej, tzn.

$$
r_{h}=\frac{2 V_{P}}{S_{P}}
$$

Bardziej realną wielkością określającą wymiar porów jest catkowita dlugość porów $l_{P}$, liczona wzdłuż pomiarowego odcinka prostej płaskiego przekroju. Inną liniową miarą wielkości porów jest średnia dtugość cięciwy $d$, określona jako średnia arytmetyczna z pomiarów cięciw pojedynczych porów.

$\mathrm{W}$ aktualnie rozwijanych badaniach nad ukierunkowanymi materiałami porowatymi wprowadza się tensorowe charakterystyki ich struktury. Przy formułowaniu związków fizycznych materiałów o konstrukcyjnej porowatości strukturę porów (otworów) charakteryzuje tensor perforacji. Dla materiałów o kanalikowej budowie struktury wewnętrznej zaproponowano tensor strukturalnej przepuszczalności. Uwzględnia on wpływ kierunkowych właściwości struktury na makroskopowe pole prędkości cieczy przepływającej przez porowaty szkielet. Geometrycznie określa wielkość i kierunki kanalików na dowolnej powierzchni przekroju materiału [7]. Również geometryczny opis konfiguracji struktury wewnętrznej, zwłaszcza w zastosowaniu do ośrodków granulowanych, reprezentuje tensor struktury (fabric tensor). Jest to symetryczny tensor drugiego rzędu opisujący wielkość i ukierunkowanie ziaren ośrodka, wykorzystywany także przy definiowaniu struktury niektórych materiałów biologicznych, np. kości.

Dla pełności opisu struktury materiału porowatego należy wymienić jeszcze współczynnik przepuszczalności, występujący w empirycznym prawie filtracji Darcy'ego, oraz krętość. Ta ostatnia wielkość jest odzwierciedleniem faktu, że tor cząsteczki cieczy $\mathrm{w}$ jej mikro-przepływie przez pory różni się od toru, jaki wynika $z$ makroskopowych (uśrednionych) warunków przepływu.

W rozważaniach dotyczących mechanicznego zachowania się nienasyconych materiałów porowatych zasadniczym problemem pozostaje określenie związków konstytutywnych. Dla wielu zagadnień fundamentalną rolę odgrywają liniowe związki naprężeń z odkształceniami, modelujące na przykład sprężyste właściwości materiału porowatego. Stałe (lub funkcje) materiałowe, charakteryzujące makroskopowo taki materiał, są modułami efektywnymi lub zastępczymi i bardzo ważną kwestią jest wyznaczenie zależności tych modułów od modułów sprężystych materiału szkieletu i parametrów charakteryzujących strukturę porów, np. porowatość, tensor perforacji itp.

Wyniki badań doświadczalnych materiałów porowatych $\mathrm{w}$ zakresie deformacji sprężystych poz- walają ustalić empiryczne zależności pomiędzy efektywnymi modułami sprężystości a porowatością objętościową. Do najprostszych relacji dla materiałów izotropowych należą związki liniowe i wykładnicze.

Wykładnicze zależności efektywnych modułów sprężystości podłużnej $E$ i poprzecznej $G$ od porowatości przyjmuje się w postaci:

$$
\begin{gathered}
E=E_{S} \exp \left(-b_{E} f_{V}\right) \\
G=G_{S} \exp \left(-b_{G} f_{V}\right)
\end{gathered}
$$

gdzie $E_{\mathrm{S}}$ i $G_{\mathrm{S}}$ są modułami sprężystości materiału szkieletu, $f_{V}$ objętościową porowatością materiału zaś $b_{E}$ i $b_{G}$ są stałymi empirycznymi. Powyższe związki wykorzystywane są w modelowaniu niektórych spieków ceramicznych. Inny przykład relacji empirycznych stanowią poniższe zależności liniowe:

$$
\begin{aligned}
& E=E_{S}\left(1-k f_{V}\right) \\
& G=G_{S}\left(1-s f_{V}\right)
\end{aligned}
$$

gdzie $k$ i $s$ są doświadczalnymi stałymi materiału porowatego. Zależności (8) stanowią pewną aproksymację związków (7) dla niewielkich porowatości $\left(f_{V} \leq 0.1\right)$ i dobrze opisują porowate spieki metali.

Możliwość stosunkowo dokładnego określenia efektywnych stałych sprężystych materiałów porowatych uzyskuje się dla regularnych struktur wewnętrznych, na przykład zbudowanych z komórek o założonych kształtach i wymiarach, drogą analitycznego lub numerycznego uśredniania. $\mathrm{W}$ wyrażeniach na efektywne moduły sprężystości występuja, jak wyżej, moduły materiału szkieletu oraz wielkości charakteryzujące strukturę wewnętrzną. Dla sprężystego materiału porowatego o strukturze wewnętrznej złożonej z sześciennych komórek zastępczy moduł Younga przyjmuje się następująco:

$$
E=\frac{2 E_{S}}{1-v^{2}} \frac{t}{a}
$$

gdzie: $a$ jest wymiarem komórki a $t$ grubością jej ścianki [16].

Dla pianek elastomerowych i polimerowych o heksagonalnym układzie komórek efektywny moduł Younga można wyrazić także $\mathrm{w}$ funkcji długości $l \mathrm{i}$ grubości $t$ ich ścianek a te $\mathrm{z}$ kolei są bezpośrednio związane z gęstością względną $\rho / \rho_{s}$ ośrodka lub jego porowatością $f_{V}$ [17], co można zapisać następująco:

$$
E=E_{S}\left(\frac{t}{l}\right)^{4}=E_{S}\left(\frac{\rho}{\rho_{S}}\right)^{2}=E_{S}\left(1-f_{V}\right)
$$

Równanie (10) dobrze opisuje pianki rzeczywiste a stopień ich spienienia umożliwia zmianę modułów $\mathrm{w}$ szerokim zakresie, np. 100-krotne zmniejszenie gęstości względnej pianki od 0.5 do 0.005 powoduje zmianę modułu $E$ aż $10^{4}$-krotnie. W dalszej części pracy 
przyjęto szczególny model struktury materiału porowatego o zmiennych modułach sprężystości $E$ i $G-$ maksymalnych na brzegach elementu i minimalnych w jego środku.

\section{Wykorzystanie modelu porowatego materiału sprężystego w ocenie wytrzymałości i stateczno- ści płyt i powłok}

Cienkościenne konstrukcje o strukturze porowatej pozwalają obecnie na podwyższenie jakości współczesnych, a tym bardziej przyszłościowych konstrukcji inżynierskich. Elementarne konstrukcje jak np. płyty i powłoki są powszechnie stosowane w złożonych strukturach i podlegaja zazwyczaj ocenie pod względem wytrzymałości lub stateczności. Istotnym problemem w wymiarowaniu tego typu konstrukcji jest określenie stanu naprężeń, ugięć oraz obciążeń krytycznych. Sformułowanie warunków wytrzymałości i stateczności lokalnej lub globalnej jest niezbędne w projektowaniu obiektów technicznych zbudowanych $\mathrm{z}$ tego typu struktur. Problemy te dla metalowych konstrukcji omówiono przykładowo $\mathrm{w}$ pracach

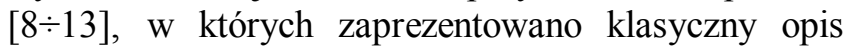
teorii płyt i powłok.

Przedmiotem badań jest płyta prostokątna o strukturze porowatej, której długość wynosi $a$, szerokość $b$, grubość $t$. Płyta zorientowana jest $\mathrm{w}$ prostokątnym układzie współrzędnych $x \quad y \quad z$, przy czym płaszczyzna $x y$ leży w płaszczyźnie środkowej płyty. Płyta wykonana jest $\mathrm{z}$ materiału jednorodnego, w którym porowatość jest zmienna po grubości $t$.

Przyjęto symetryczną zmianę modułu sprężystości materiału płyty względem jej płaszczyzny środkowej (rys.1). Zmianę tę możemy wyrazić np. za pomoca funkcji, którą przyjęto jak dla belki porowatej na podstawie pracy [14], w postaci:

$$
E(z)=E_{1}\left[1-e_{0} \cos (\pi \zeta)\right]
$$

gdzie:

$\zeta=\frac{z}{t}-$ bezwymiarowa współrzędna,

$e_{0}=1-\frac{E_{0}}{E_{1}}-$ współczynnik porowatości płyty,

$E_{0}, E_{1}$, - moduły sprężystości dla $\zeta=0$ i $\zeta= \pm \frac{1}{2}$.

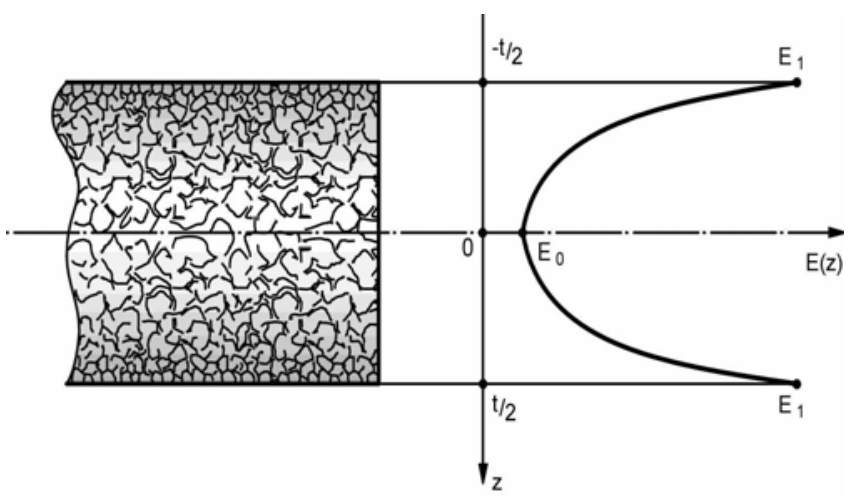

Rys.1. Graficzna ilustracja zmiany modułów sprężystości podłużnej E po grubości płyty

Schemat przemieszczeń przekroju poprzecznego płyty $\mathrm{w}$ stanie przed obciążeniem i po obciążeniu pokazano na rys. 2 .

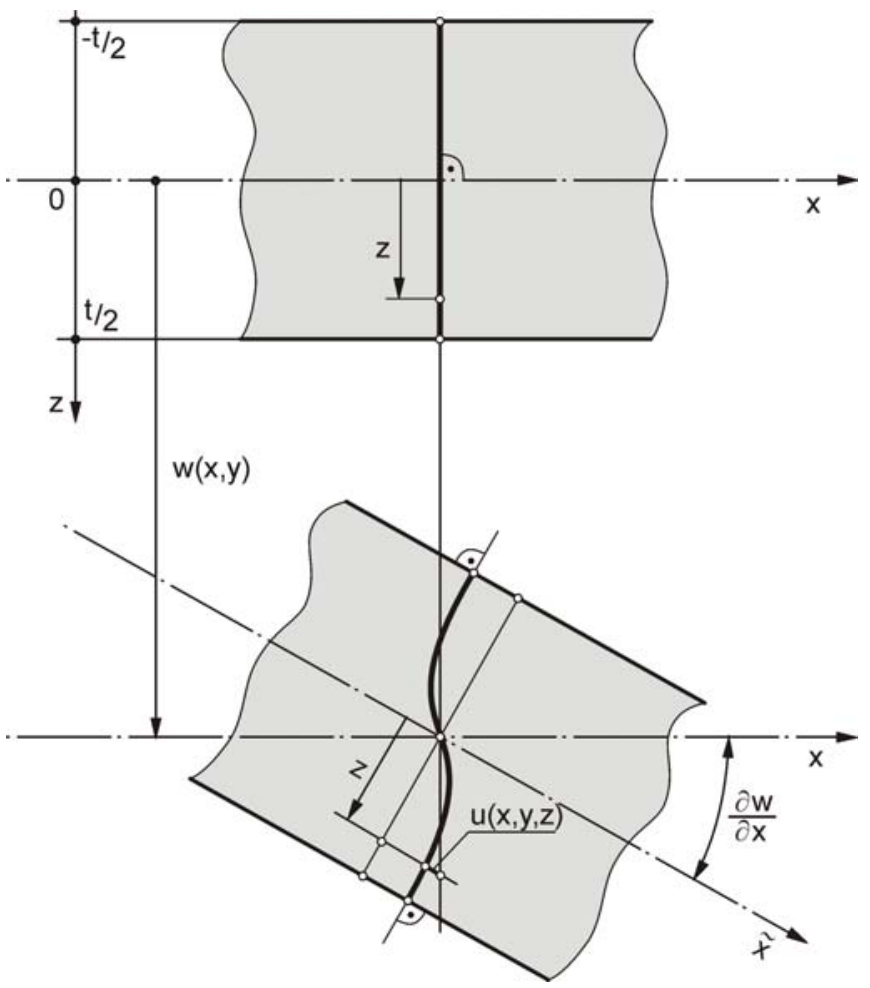

Rys.2. Przemieszczenia w przekroju poprzecznym ścianki płyty

Pole przemieszczeń dla badanej płyty zdefiniowano na podstawie pracy [14] w następujący sposób:

$$
\begin{aligned}
& u(x, y, z)=-t\left\{\zeta \frac{\partial w}{\partial x}-\frac{1}{\pi}\left[\psi_{1}(x, y) \sin (\pi \zeta)+\psi_{2}(x, y) \sin (2 \pi \zeta) \cos ^{2}(\pi \zeta)\right]\right\} \\
& v(x, y, z)=-t\left\{\zeta \frac{\partial w}{\partial y}-\frac{1}{\pi}\left[\phi_{1}(x, y) \sin (\pi \zeta)+\phi_{2}(x, y) \sin (2 \pi \zeta) \cos ^{2}(\pi \zeta)\right]\right\} \\
& w(x, y, z)=w(x, y, 0)=w(x, y) \text { - ugięcie płyty }
\end{aligned}
$$


gdzie: $\psi_{1}(x, y), \psi_{2}(x, y), \phi_{1}(x, y), \phi_{2}(x, y)$ - bezwymiarowe funkcje przemieszczeń.

Można także otrzymać klasyczne rozwiązanie dla płyty w przypadku, gdy współczynnik porowatości $e_{0}=0$. Na podstawie zależności (12), (13) i (14) wyprowadzono składowe pola odkształceń-związki geometryczne dla geometrycznie liniowej teorii. Zasada stacjonarności całkowitej energii potencjalnej płyty wyrażona jest zależnością:

$$
\delta\left(U_{\varepsilon}-W\right)=0,
$$

gdzie:

$U_{\varepsilon}=\frac{t}{2} \iint_{\Omega}^{1 / 2} \int_{-1 / 2}^{1 / 2}\left(\sigma_{x} \varepsilon_{x}+\sigma_{y} \varepsilon_{y}+\tau_{x y} \gamma_{x y}+\tau_{x z} \gamma_{x z}+\tau_{y z} \gamma_{y z}\right) d x d y d \zeta$

- energia odkształcenia, w której przyjęto liniowe związki fizyczne (prawo Hooke'a),

$W=\iint_{\Omega}\left[p \cdot w+\frac{1}{2} N_{x}\left(\frac{\partial w}{\partial x}\right)^{2}+\frac{1}{2} N_{y}\left(\frac{\partial w}{\partial y}\right)^{2}\right] d x d y$

- praca obciążenia, przy czym $p$ - ciśnienie oraz $N_{x}, N_{y}$ - intensywności obciążeń.
Po wykonaniu całkowania otrzymano układ pięciu równań różniczkowych, które rozwiązano w sposób przybliżony, przyjmując nieznane funkcje $\mathrm{w}$ postaci:

$w(x, y)=w_{a} \cdot \sin \frac{m \pi x}{a} \sin \frac{n \pi y}{b}, \quad m=1,2, \ldots, \quad n=1,2, \ldots$

$\psi_{k}(x, y)=\psi_{a k} \cdot \cos \frac{m \pi x}{a} \sin \frac{n \pi y}{b}, \quad k=1,2, \ldots$

$\phi_{k}(x, y)=\phi_{a k} \cdot \sin \frac{m \pi x}{a} \cos \frac{n \pi y}{b}, \quad k=1,2, \ldots$

gdzie:

$w_{a}$ - strzałka ugiecia, $\psi_{a k}, \phi_{a k}$ - parametry funkcji.

$\mathrm{Na}$ podstawie rozwiązania można otrzymać bezwymiarową strzałkę ugięcia płyty $\widetilde{w}_{a}=\frac{w_{a}}{t}$ lub obciążenia krytyczne $N_{x, K R}, N_{y, K R}$. W przypadku, gdy porowata płyta prostokątna obciążona jest równomiernym obciążeniem $p_{0}, \mathrm{z}$ warunku ortogonalizacyjnego metody Bubnowa i Galerkina otrzyma się:

$$
\widetilde{w}_{a}=\frac{16}{\pi^{5}} \frac{1-v^{2}}{k_{0}} \frac{p_{0}}{E_{1}}
$$

gdzie:

$$
\begin{aligned}
& k_{0}=\left\{\pi\left[1+\left(\frac{a}{b}\right)^{2}\right] C_{1} \frac{t}{a}-\left(C_{2}+C_{3} C_{10}\right)\left(\alpha_{1}+\frac{a}{b} \beta_{1}\right)\right\}\left[1+\left(\frac{a}{b}\right)^{2}\right]\left(\frac{t}{a}\right)^{3}, \text { oraz } m=n=1 . \\
& C_{1}=\frac{1}{12}\left(1-6 \frac{\pi^{2}-8}{\pi^{3}} e_{0}\right), \quad C_{2}=\frac{1}{\pi^{2}}\left(\frac{2}{\pi}-\frac{1}{4} e_{0}\right), \quad C_{3}=\frac{1}{\pi^{2}}\left(\frac{3}{16}-\frac{32}{75 \pi} e_{0}\right), \\
& C_{4}=\frac{1}{\pi^{2}}\left(\frac{1}{2}-\frac{2}{3 \pi} e_{0}\right), \quad C_{5}=\frac{1}{\pi^{2}}\left(\frac{8}{15 \pi}-\frac{1}{8} e_{0}\right), \quad C_{7}=\frac{1}{2}-\frac{4}{3 \pi} e_{0}, \\
& C_{8}=\frac{8}{15 \pi}-\frac{1}{4} e_{0}, \quad C_{10}=\frac{C_{3} C_{7}-C_{2} C_{8}}{C_{2} C_{7}-C_{3} C_{8}}, \quad \alpha_{1}=\frac{a_{22} b_{1}-a_{12} b_{2}}{a_{11} a_{22}-a_{12}^{2}}, \quad \beta_{1}=\frac{a_{11} b_{2}-a_{21} b_{1}}{a_{11} a_{22}-a_{12}^{2}}, \\
& a_{11}=\left(C_{4}+C_{5} C_{10}\right)\left[1+\frac{1-v}{2}\left(\frac{n}{m} \frac{a}{b}\right)^{2}\right]\left(m \pi \frac{t}{a}\right)^{2}+\frac{1-v}{2}\left(C_{7}+C_{8} C_{10}\right), \\
& a_{12}=\frac{1+v}{2}\left(C_{4}+C_{5} C_{10}\right) m n \pi^{2} \frac{t^{2}}{a b}, b_{1}=C_{2}\left[1+\left(\frac{n}{m} \frac{a}{b}\right)^{2}\right]\left(m \pi \frac{t}{a}\right)^{3}, \\
& a_{22}=\left(C_{4}+C_{5} C_{10}\right)\left[\frac{1-v}{2}+\left(\frac{n}{m} \frac{a}{b}\right)^{2}\right]\left(m \pi \frac{t}{a}\right)^{2}+\frac{1-v}{2}\left(C_{7}+C_{8} C_{10}\right), b_{2}=C_{2}\left[1+\left(\frac{n}{m} \frac{a}{b}\right)^{2}\right] m^{2} n \pi^{3} \frac{t^{3}}{a^{2} b} .
\end{aligned}
$$

Maksymalne naprężenia (na podstawie prawa Hooke'a) wystęujące w geometrycznym środku $(x=a / 2, y=b / 2)$ wynoszą:

$$
\begin{aligned}
& \sigma_{x}=\frac{16}{\pi^{5} k_{0}} \frac{t}{a}\left\{\pi^{2} \frac{t}{a}\left[1+v\left(\frac{a}{b}\right)^{2}\right] \zeta-\left(\alpha_{1}+v \beta_{1} \frac{a}{b}\right)\left[\sin (\pi \zeta)+C_{10} \sin (2 \pi \zeta) \cos ^{2}(\pi \zeta)\right]\right\} f_{e} \cdot p_{0} \\
& \sigma_{y}=\frac{16}{\pi^{5} k_{0}} \frac{t}{a}\left\{\pi^{2} \frac{t}{a}\left[v+\left(\frac{a}{b}\right)^{2}\right] \zeta-\left(v \alpha_{1}+\beta_{1} \frac{a}{b}\right)\left[\sin (\pi \zeta)+C_{10} \sin (2 \pi \zeta) \cos ^{2}(\pi \zeta)\right]\right\} f_{e} \cdot p_{0}
\end{aligned}
$$

gdzie: $\quad f_{e}=1-e_{0} \cos (\pi \zeta)$ 
Przykład rozkładu naprężeń po grubości płyty w jej geometrycznym środku zamieszczono na rys.3. Rodzina krzywych została wykonana dla różnych wartości współczynnika porowatości $\mathrm{e}_{0}$ oraz $\frac{a}{b}=1$, $v=0.3, E_{1}=2.05 \cdot 10^{5} \mathrm{MPa}, p_{0}=1 \mathrm{MPa}$.

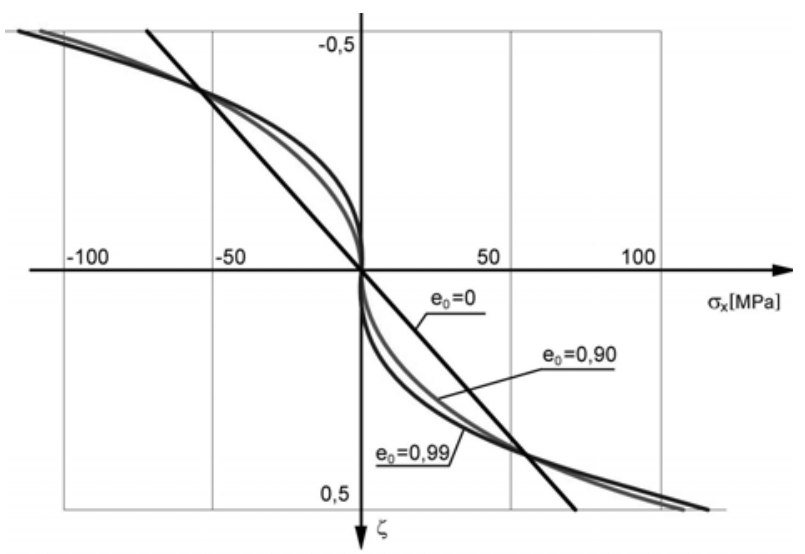

Rys.3. Rozkład naprężeń normalnych $\sigma_{x}$ po grubości płyty

$$
(t / a=1 / 15)
$$

Otrzymane wyniki potwierdzają dużą zgodność $\mathrm{z}$ wynikami obliczeń wykonanych za pomocą MES. Dla zbadanej rodziny płyt kwadratowych różnica ta nie przekracza $1.8 \% \mathrm{~W}$ przypadku ugieć oraz $6 \%$ dla naprężen. Dla płyt obciążonych tarczowo siłami jednostkowymi $N_{x}, N_{y}$ otrzymano zależność na bezwymiarowe obciążenie krytyczne:

$$
f_{x, K R}=\left(1-v^{2}\right)\left(\frac{N_{x}}{E_{1} t}\right)_{K R}=\min _{m, n}\left\{m \pi \frac{t}{a} \cdot k_{1} \frac{1+k_{2}^{2}}{1+C_{x y} k_{2}^{2}}\right\}
$$

gdzie:

$$
\begin{aligned}
& k_{1}=m \pi \frac{t}{a}\left(1+k_{2}^{2}\right) C_{1}-\left(C_{2}+C_{3} C_{10}\right)\left(\alpha_{1}+\beta_{1} k_{2}\right) \\
& k_{2}=\frac{n}{m} \frac{a}{b}, \quad C_{x y}=N_{y} / N_{x} .
\end{aligned}
$$

Podobne zadanie dla belki wykonanej z materiału porowatego rozwiązano w pracy [15].

W przypadku powłoki-paneli walcowej przyjęto walcowy układ współrzędnych $x \quad \varphi \quad z$, przy czym powierzchnia $x \varphi$ leży $\mathrm{w}$ płaszczyźnie środkowej powłoki. Porowata powłoka-panel walcowa ma długość $L$, kąt wycinka $\beta(b=r \beta)$, promień powłoki $r$ i grubość $t$. Pole przemieszczeń dla badanej powłoki zdefiniowano w następujący sposób:

$u(x, \varphi, z)=u_{0}(x, \varphi)-t\left[\zeta \frac{\partial w}{\partial x}-\frac{1}{\pi} \psi_{1}(x, \varphi) \sin (\pi \zeta)\right]$

$v(x, \varphi, z)=v_{0}(x, \varphi)-t\left[\zeta \frac{\partial w}{r \partial \varphi}-\frac{1}{\pi} \phi_{1}(x, \varphi) \sin (\pi \zeta)\right]$

$w(x, \varphi, z)=w(x, \varphi, 0)=w(x, \varphi)-$ ugięcie powłoki, (21) gdzie:

$u_{0}(x, \varphi), \quad v_{0}(x, \varphi)$ - przemieszczenia styczne dowolnego punktu powierzchni środkowej.

W analogiczny sposób jak dla płyty wyprowadzono równanie na bezwymiarowe ugięcie geometrycznego środka powłoki obciążonej ciśnieniem $\mathrm{p}_{0}$ :

$$
\widetilde{w}_{a}=\frac{16}{\pi^{2}} \frac{1-v^{2}}{k_{s}} \frac{p_{0}}{E_{1}}
$$

gdzie:

$$
\begin{aligned}
& k_{s}=\pi \frac{t}{L}\left\{\left(\pi \frac{t}{L}\right)^{2}\left(1+k_{c}^{2}\right)\left[\pi \frac{t}{L} C_{1}\left(1+k_{c}^{2}\right)-C_{2}\left(\alpha_{\psi}+k_{c} \alpha_{\phi}\right)\right]+\frac{t}{r} C_{0}\left(v \alpha_{u}+k_{c} \alpha_{v}+\frac{L}{\pi r}\right)\right\}, \\
& m=n=1, \alpha_{\psi}=\frac{a_{22} b_{1}-a_{12} b_{2}}{a_{11} a_{22}-a_{12}^{2}}, \alpha_{\phi}=\frac{a_{11} b_{2}-a_{21} b_{1}}{a_{11} a_{22}-a_{12}^{2}}, a_{11}=C_{4}\left(1+\frac{1-v}{2} k_{c}^{2}\right)\left(m \pi \frac{t}{L}\right)^{2}+\frac{1-v}{2} C_{7}, \\
& a_{12}=m n \pi^{2} \frac{1+v}{2} \frac{t^{2}}{L r \beta} C_{4}, b_{1}=C_{2}\left(1+k_{c}^{2}\right)\left(m \pi \frac{t}{L}\right)^{3}, b_{2}=C_{2}\left(1+k_{c}^{2}\right) m^{2} n \pi^{3} \frac{t^{3}}{L^{2} r \beta}, \\
& a_{22}=C_{4}\left(\frac{1-v}{2}+k_{c}^{2}\right)\left(m \pi \frac{t}{L}\right)^{2}+\frac{1-v}{2} C_{7}, k_{c}=\frac{n}{m} \frac{L}{r \beta}, \alpha_{u}=\frac{L}{m \pi r} \frac{k_{c}^{2}-v}{\left(1+k_{c}^{2}\right)^{2}}, \alpha_{v}=\frac{n}{m^{2}} \frac{L^{2}}{r^{2} \pi \beta} \frac{2+v+k_{c}^{2}}{\left(1+k_{c}^{2}\right)^{2}}, \\
& C_{0}=1-\frac{2}{\pi} e_{0}
\end{aligned}
$$

Pozostałe oznaczenia jak we wzorze (16). 
W przypadku obciążenia powłoki-paneli walcowej równomiernym ciśnieniem $p_{0}$, czyli ściskania w kierunku obwodowym siłami rozłożonymi równomiernie na brzegach prostoliniowych o stałej intensywności $N_{\varphi}=r p_{0}$, a także ściskania wzdłuż tworzących siłami rozłożonymi na brzegach krzywoliniowych o stałej intensywności $N_{x}$, otrzyma się zależność na bezwymiarowe obciążenie krytyczne:

$$
f_{x, K R}=\left(1-v^{2}\right)\left(\frac{N_{x}}{E_{1} t}\right)_{K R}=\min _{m, n}\left[k_{s 3}\left(k_{s 3} C_{1}-k_{s 4} C_{2}\right)+k_{s 5} C_{0}\right]
$$

gdzie:

$$
\begin{aligned}
& k_{s 3}=m \pi \frac{t}{L}\left[1+\left(\frac{n}{m} \frac{L}{r \beta}\right)^{2}\right], \\
& k_{s 4}=\alpha_{\psi}+\frac{n}{m} \frac{L}{r \beta} \alpha_{\phi}, \\
& k_{s 5}=\frac{L}{m \pi r}\left(v \alpha_{u}+\frac{n}{m} \frac{L}{r \beta} \alpha_{v}+\frac{L}{m \pi r}\right) .
\end{aligned}
$$

Przykład utraty stateczności porowatej powłoki obciążonej ciśnieniem zewnętrznym $\mathrm{p}_{0}$, obliczonej za pomoca MES (program ANSYS) przedstawiono na rys.4, gdzie $\frac{L}{r \beta}=1 ; \beta=\pi / 2 ; e_{0}=0.99$.
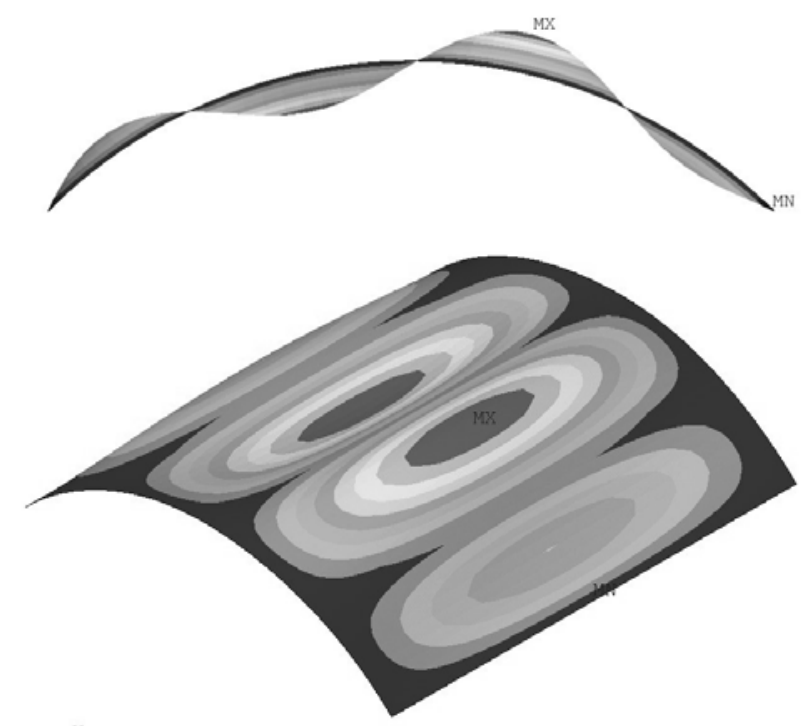

Rys.4. Utrata stateczności powłoki pod wpływem ciśnienia $\mathrm{p}_{0}$

Wartości bezwymiarowych obciążeń krytycznych wyrażonych zależnością (23) należy poszukiwać metodami numerycznymi. Dla powłoki pod działaniem ciśnienia zewnętrznego $\mathrm{p}_{0}\left(N_{x}=0\right)$ otrzymano natomiast wyrażenie:

$$
\left(1-v^{2}\right) \frac{r}{t}\left(\frac{p_{0}}{E_{1}}\right)_{K R}=\min _{m, n}\left\{\left(\frac{m}{n} \frac{r \beta}{L}\right)^{2}\left[k_{s 3}\left(k_{s 3} C_{1}-k_{s 4} C_{2}\right)+k_{s 5} C_{0}\right]\right\}
$$

Oznaczenia jak we wzorach (16) i (22).

Przedstawiony model analityczny płyty i powłoki wykonanej $\mathrm{z}$ materiału porowatego oraz zastosowane metody dają przybliżone rozwiązania zadań ze statyki i stateczności. Wyniki przeprowadzonych obliczeń numerycznych metodą elementów skończonych potwierdzają słuszność wyprowadzonych związków. Na podstawie przedstawionych zależności na naprężenia, ugięcia oraz bezwymiarowe obciążenia krytyczne można ocenić w praktyce inżynierskiej wytrzymałość i stateczność jednorodnych płyt i powłok o strukturze porowatej.

Przykłady obliczeń wytrzymałości i stateczności elementów powierzchniowych, wykonanych $\mathrm{z}$ konkretnego materiału o strukturze porowatej, będa podane w kolejnej publikacji.

\section{Literatura}

[1] Bossak M., Teoretyczne i doświadczalne opracowanie metody wyznaczania dynamicznych wtasności konstrukcji, Dysertacja, Politechnika Warszawska, Warszawa 1969.

[2] Bubnicki Z., Identyfikacja obiektów sterowania, PWN, Warszawa 1975.

[3] Giergiel J., Identyfikacja układów mechanicznych, 12 Sympozjum „Drgania w układach fizycznych”, Poznań-Błażejewko 1986.

[4] Kamiński E., Podstawowe metody identyfikacji drganiowej i diagnostyki maszyn, Dynamika maszyn, Ossolineum, Wrocław 1974.

[5] Dudziak M., Mielniczuk J., Nieklasyczne modele materiatów w projektowaniu maszyn, Wydawnictwo ITE, Poznań - Radom 2001

[6] Osiecki Z., Elementy modelowania $w$ dynamice maszyn. Dynamika maszyn, Ossolineum, Wrocław 1974.

[7] Mielniczuk J., Plasticity of porous materials, Wydawnictwo Politechniki Poznańskiej, Poznań 2000.

[8] Bažant Z.P., Cedolin L., Stability of structures. Oxford University Press, New York, Oxford. 1991.

[9] Timoshenko S., Woinowsky-Krieger S., Theory of plates and shells, McGraw-Hill Book Company, Inc, New York, Toronto, London. 1959.

[10] Singer J., Arbocz J., Weller T., Buckling experiments. Experimental methods in buckling of thin-walled structures, John Wiley \& Sons, Inc. New York. 1998.

[11] Życzkowski M. red., Wytrzymatość elementów konstrukcyjnych, PWN, Warszawa 1988.

[12] Kaczkowski Z., Ptyty-obliczenia statyczne, Arkady, Warszawa 1980.

[13] Nowacki W., Dźwigary powierzchniowe, PWN, Warszawa 1980

[14] Magnucki K., Stasiewicz P., Elastic bending of an isotropic porous beam, Int. Journal of Applied Mechanics and Engineering, 9, (2), 2004.

[15] Magnucki K., Stasiewicz P., Elastic buckling of a porous beam, Int. Journal of Theoretical and Applied Mechanics, 42, (4), 2004.

[16] Flügge $W$., Tensor analysis and continuum mechanics, Springer-Verlag, Berlin 1972.

[17] Ashby M. F., Jones D. R., Materialy inżynierskie, t. 2, WNT, Warszawa 1996. 